Redaksjonelt

\title{
En fornøyd, men litt umoden tiåring?
}

Tidsskriftet Sakprosa

Bind 11, Nummer 2

(C) 2019 
I år fyller Tidsskriftet Sakprosa fyller ti år. Et slikt jubileum gir anledning til litt selvkritisk - og gjerne også selvtilfreds - refleksjon. 7. mars i år møttes store deler av redaksjonsrådet og redaksjonen i Helsingfors for å evaluere tidsskriftet, generelt og gjennom dypdykk i et utvalg enkeltartikler fra de siste fem årene.

Til diskusjonen hadde vi invitert professor Srikant Sarangi, redaktør for ikke mindre enn tre internasjonale tidsskrifter: Text \& Talk, Communication \& Medicine og Journal of Applied Linguistics and Professional Practice. Sarangi ga uttrykk for at det er viktig med regionale tidsskrifter av Sakprosas type, som gjerne kan publisere på regionens språk, og som kan stimulere til løpende gransking av forhold som er særlig aktuelle i regionen.

I dette tilfelle gjelder det det særnordiske begrepet «sakprosa» og dets forankring i den nordiske samfunnsmodellen. Framfor alt gjelder det de mange tekstene som sakprosabegrepet kan gi ekstra mening til. Dette er tekster og sjangere som er knyttet til et vell av ulike institusjoner og sfærer i Norden, fra parnassets litteratur til arbeids- og hverdagsliv. Men det er også viktig å tenke tidsskriftet inn i en internasjonal sammenheng, både ved å gjøre titler og abstracts lett søkbare, og ved at artiklene som en selvfølge refererer til relevant forskning også fra andre deler av verden. Derfor utstyrer vi fra og med dette nummer - seint, men forhåpentligvis godt - alle artikler med parallelle skandinaviske og engelske titler og nøkkelord, og vi oppfordrer forfatterne til både å beholde den regionale forankringen og å være i dialog med den internasjonale forskningsfronten.

Og så vil vi enda mer enn før tilstrebe en god tematisk og metodisk spredning på sakprosaens store felt. Det betyr ikke at vi skal bringe «litt om alt», men at vi skal belyse ulike deler av sakprosaens rike tekstverden med forskjellige slags lyskilder, slik at vi etter de neste ti årene kan se sporet av et innebygd, pluralistisk forskningsprogram. 


\section{Forfriskende om eksempler, metaforer og legitimeringsstrategier}

Hvilken rolle spiller eksemplet i sakprosatekster? Selvsagt er de nettopp eksempler på ulike fenomener, spørsmål eller påstander. Men de kan også spille en rolle langt utover dette - de kan leve sitt eget liv, hinsides det de skulle eksemplifisere, i erkjennelsens og den politiske forståelsens tjeneste. Det er temaet for Brian Benjamin Hansens artikkel i dette nummeret, der vi særlig skal bli kjent med dette fenomenet i Slavoj Žižeks forfatterskap.

Hvordan legitimerer nordiske alkoholmonopoler sin eksistens overfor publikum? Deres paradoksale budskap - at vi må drikke mindre, men gjerne kjøpe monopolenes utmerkede produkter - blir fremmet på ulikt vis i de ulike landene. Artikkelen «Monopolets moral: de nordiska alkoholmonopolens legitimeringsarbete» inneholder foruten internordisk sammenlikning en nærmere undersøkelse av det svenske Systembolaget, og her framkommer det tydelige historiske endringer. Både forskjellene og endringene blir i Henrik Rahms, Sanna Skärlunds og Peter Svenssons artikkel sett i lys av særskilte trekk ved de ulike nordiske landene og av allmenne kulturelle og politiske endringer.

Og hvordan formidler den verdensomspennende organisasjonen Leger uten grenser sitt budskap om nødvendigheten av å yte bistand? Anna Vogel har tatt i bruk kognitiv metaforteori for å få øye på hva som formidles på organisasjonens svenske hjemmeside. «Slutsatsen blir att organisationen förmedlar en komplex bild av bistånd som meningsfullt, nödvändigt och politiskt.»

Dermed kan Vogels studie kanskje gi ideer til andre bistandsorganisasjoner som ikke nyter den samme store tillit som Médicins sans frontièrs. I så fall lever artikkelen opp til et EU-krav til forskning som de siste par årene har kommet på alle akademikeres lepper: Den har impact. Men det kan vel også 
analysen av vinmonopolene ha? Den kommunikasjonsdirektør i et nordisk monopol eller den helsepolitiker som leser Rahms, Skärlunds og Svenssons artikkel, vil kunne få noen nye briller å lese gjennom og en ny penn å skrive strategidokumenter med. Og neste gang vi møter et slående eksempel - eller selv strever med å finne og formulere vårt eget- vil vi tenke annerledes om eksemplets potensial enn vi gjorde før vi leste Hansens artikkel. Impact der også, altså.

\section{Uhøytidelig konkurranse}

Hvem er leserne av tidsskriftet Sakprosa? Ofte vil det være lesere som har lett seg fram til én enkelt artikkel. Imidlertid ønsker vi oss en fast leserkrets. Burde ikke kjernen i denne kretsen være tidsskriftets egne forfattere? I tiden framover kommer vi jevnlig til å sende ut noen korte brev til samtlige som til enhver tid har bidratt med artikler i tidsskriftet. Både de og alle andre lesere av denne lederartikkelen inviteres her og nå til innen 1. juni 2019 å sende inn sitt begrunnede forslag til hva som har vært den aller beste artikkelen i Sakprosa siden opprettelsen i 2009. Det blir små premier til dem som kommer med forslag og en litt større premie til forfatteren/forfatterne av vinnerartikkelen. Send forslaget merket «Best Sakprosa» til johan.tonnesson@iln.uio.no!

Johan L. Tønnesson 